\title{
THE NATIONAL INSTITUTE FOR RESEARCH IN DAIRYING
}

\author{
REPORT FOR 1963
}

$\mathrm{T}$ HE average townsman rarely thinks of Britain as a country famous for dairying, and yot it possesses one of the biggest and best-organized dairy industries in the world. The milk it produces annually is worth about $£ 400$ million, and it supplies all the liquid milk and a proportion of the milk products consumed by the country's population of some 53 million people. Even in the early years of the present century, when dairying was not nearly so widespread or so intensive as it is to-day, the importance of research in such an industry was beginning to be appreciated, with the result that in 1912 a research institute in dairying was founded at Reading. In the first year or so of the Institute's existence the main members of the staff consisted of one chemist and one bacteriologist and the Governmont grant for maintenance was only $£ 1,510$. Little did the pioneers of these early days imagine that in about fifty years this very small new Institute would grow to such an extent that its staff, as listed in its report for $1963 *$, would number more than 400 , of whom more than 100 would be fully qualified in some branch of science.

As now constituted the Institute has ten main Departments: Physics; Chemistry; Physiology; Nutrition; Radiobiochemistry; Bacteriology ; Chemical Microbiology; Feeding and Metabolism; Dairy Husbandry; Engineering. There are also an Experimental Dairy, a Statistics Section and one of the best libraries on dairying and related sciences in the world. In addition to this, the Institute is admirably situated, being surrounded by four farms of its own which provide it with three dairy herds and an area of more than 800 acres, all of which can be available for research.

The work done in the various Departments ranges from fundamental research of first-class quality in the basic sciences on which dairying depends to problems of immediate practical application in the dairy world. In a short article such as this it is impossible to cite more than one or two of the many topies that have been investigated so effectively in the past year.

As an example of the more fundamental type of work it may be mentioned that in the Physiology Department, for example, research is being done on the citric acid cycle in mammary tissue. Work with ${ }^{2-{ }^{14} \mathrm{C} \text {-propionate has }}$ suggested that propionate enters the citric acid cycle as oxaloacetate, and it seems likely that the conversion of propionate to oxaloacetate is catalysed by soluble cytoplasmic enzymes and not by those of the mitochondria. This particular type of formation of the intermediates of the citric acid cycle could be an important step in the synthesis of fatty acids in the mammary gland. Then again, in important work by the Radiobiochemistry

* University of Reading: National Institute for Research in Dairying. Report 1963. Pp. 172. (Shinfleld, Berkshire: National Institute fo Research in Dairying, 1964.) 78. 6d.
Department on the part played by dietary fat in the formation of millk fat, experiments have been made in which dietary fat labelled with tritium has been given to the lactating cow. The results have shown that newly absorbed fat circulates in the plasma mainly in the form of lipoprotein triglycerides ( $\beta$-lipoproteins), and that these particular lipoproteins are preferentially selected by the mammary gland from the lipids in the blood. It was found that the specific activity of the labelled triglycerides normally reached a maximum only some 6 hours earlier than the maximum was reached in the milk lipids, and it seems certain that dietary fat rapidly becomes available to the mammary gland in the form of these $\beta$-lipoproteins.

One or two examples of the more immediate practical aspects of the Institute's work may also be cited. In the Chemical Microbiology Department the use of gas chromatography for the assessment of mllk quality is being investigated. By distributing a small sample of milk over the inner surface of a vertical tube through which a suitable entrapping gas is passed, the volatile compounds from the milk can be transferred to a chromatogram in about 20 sec, and it is hoped that it may soon be possible to inject the milk direct on to the chromatogram. In due course the method may become so rapid and informative that it would lead to the development of an acceptable chromatographic rejection test for milk of poor quality in creameries, a test which at present relies largely on the sense of smell of the operator on the creamery reception platform. An apparatus has been developed which indicates the time after renneting at which the viscosity of milk starts to change, and a torsiometer has bcen devised which measures the rate of setting of milk in the cheese vat and gives a signal when the curd is of the right firmness for cutting. This latter instrument is already in use commercially. On the farming side, work has been done on factors which affect the amount of silage eaten by cattle, on the shape of cattle yards that require minimum amounts of litter and on an effective method of cleaning milking parlours. It is good to know that in one and the same Institute important work of a basic scientific nature proceeds alongside research on items of such immediate practical interest. Such a programme seems ideal for an institute of this type, which must always be actively concerned about the problems of the industry that it exists to serve, and yet which realizes that the practical problems of the future are most likely to bo satisfactorily solved by making a thorough study of the basic scientific facts to-day.

About 130 papers on the work of the Institute were published by its staff in the year under review, and it received some 1,700 visitors. The Institute is certainly maintaining the high standard it has achieved over the years, and it richly deserves the high esteem in which it is held throughout the world.

\section{DEVELOPMENTS IN THE GAS INDUSTRY}

GINGULARLY interesting developments havo recently been taking place in the gas industry, which were referred to by Sir Henry Jones, chairman of the Gas Council, in a lecture to the Royal Society of Arts, entitled "The Gas Industry-To-day and To-morrow", on April 22. Furthermore, in Great Britain manufactured gas may within the lifetime of some of us be replaced by natural gas.

Of the changes that have occurred since 1949 thero has been a reorganization of gas-making practice, and the former number of some 1,050 gasworks has been reduced to about 300 . Half the gas made is still produced by the carbonization of coal in progressively improved plants, but due to changing economies arising from the competitive prices of imported oil an increasing proportion of gas is now being made from oil or oil gases. In addition, in 1964, liquid natural gas is expected to be imported from North Africa. It will be carried in 12,000-ton cargo vessels from Arzew in Algeria, to Canvey Island on the Thames. 
and then transported 350 miles by pipeline to supplement the supply of towns gas. This main, reaching as far as Manchester and Leeds, will operate at a pressure of $1,000 \mathrm{lb}$./in. ${ }^{2}$ to bring methane for enrichment purposes to some eight area Gas Boards.

New works have been built for the gasification of coal at high pressure by the well-known Lurgi process, at Westfield in Scotland, and at Coleshill in the West Midlands. The use of high pressure at 20 or more atmospheres results from the technical needs of the process, but it has the compensating advantage that distribution problems are considerably reduced.

In the growing trends of turning towards oil gasification for towns, gas manufacture light petroleum distillates, byproducts of the oil refinery, have come very much into the picture. Since the advantages of chemical reactivity by catalytic reaction are applicable in this practice quite a number of new and compact processes have been evolved to meet the gas industry's nceds. This progress has boen accompanied by an acceleration of the design of new and improved equipment for the utilization of gas for both domestic and industrial purposes. A further point arising from the more novel processes that are likely to come into use is that the calorific value of the gas to be supplied will be higher than is customary to-day.

Sir Henry considered most significant the situation that may arise as foreshadowed by the discovery of a large natural gas field at Groningen in the north of Holland. Minor deposits of natural gas have been known for many years to exist in Great Britain, thus at Whitby and at Cousland in Scotland. The tremendous size of the finds of gas in Holland, however, has stimulated interest in the North Sea. At a distant epoch in geological history ancient seas covered part of North Europe, the whole of the North Sea and part of Great Britain. Deposits in these seas containing organic matter of animal and vegetable origin were covered by further rocks including those now represented by Permian Sandstones. These in turn were covered by salt layers and shales, now found to be buried in Holland at a depth of $10,000 \mathrm{ft}$. Fortunately for the Dutch, the hydrocarbon gases produced have been trapped in a reservoir rock, probably a porous sandstone, beneath the impervious salt and shales. If, as is believed to be almost certain, the rocks under the North Sea are of similar pattern and character to those under Holland and East Yorkshire, the presence of gas off shore is probable, and in large quantities. The accepted methods of seismic exploration are being undertaken and if the results are promising drilling will be undertaken. The matter lies at present in the domain of conjecture, and the prospects are difficult to assess. Nevertheless, these possibilities and the actual developments in hand, together with a possible hardening of world prices of oil as the demand increases, may well accelerate the prospects of gaseous fuel utilization in Britain. An added advantage this fuel possesses is its favourable features from the aspect of its efficient use.

As to the prospects of coal utilization in this context, a change in world availability of hydrocarbon oils and gases may make more attractive the extraction of coal by automative mining methods. Having in mind also the growing development of nuclear energy, Sir Henry Jones envisaged as a possibility the hydrogenation of coal, using hydrogen produced with the aid of nuclear heat, becoming the basis of gas production. Indeed, in this respect the Gas Council is conducting important lines of research into the hydrogenation and gasification of coal.

In a technological age, whatever may be the means, the ultimate target of a national heat and power policy must be the distribution of energy either through a wire or a pipe. The last-named should inevitably be the domain of the gas industry, which from this encouraging record is definitely making substantial strides in the needed directions.

\section{R. J. SARJANT}

\section{BRITISH CONTINENTAL SHELF PETROLEUM}

$\mathrm{D}$ ESPITE allurements of the discovery in 1959 of the major natural gas field in the province of Groningen in Holland, also intensive geophysical search for favourable geological structures beneath the North Sea by international petroleum interests since then (Nature, 200, $123 ; 1963$, and 201,$670 ; 1964)$, oil and gas potentialities of rocks lying beneath that sea-bed, at least the British sector of its continental shelf, still remain an unknown quantity. It is in this particular context that the Government's recent plans for exploration and production of oil and gas in the North Sea region must be interpreted. The newly published Act (S.I. 1964 No. 708, Continental Shelf Petroleum: The Petroleum (Production) (Continental Shelf and Territorial Sea) Regulations 1964. Pp. 20. London: H.M.S.O., 1964. 1s.) ceme into operation on May 15. It is clearly framed in unusually cautious and restrained terms and rightly so. The Groningen gas field lies some 150 miles east of the 'first designated area' of the British part of the shelf. Geologically much can happen to the rocks, equally to their hydrocarbon contents (if any), in far less than that distance in such a variable stratigraphical environment as the North Sea basin is likely to disclose. Justification for this search is technically not in question, but at least this Act ensures that, whatever the outcome, Britain's interests are henceforward amply safeguarded.

The Minister of Power, Mr. Erroll, in the House of Commons on April 7, described five main factors which, under this Act, will govern award of licences to operators to continue or to initiate search for oil, ultimately to produce if commercial quantities are found. He is reported thus: "First, the need to encourage the most rapid and thorough exploration ard economical exploitation of petroleum resources on the continental shelf. Secondly, the requirement that the applicant for a licence shall be incorporated in the United Kingdom and the profits of the operations shall be taxable here. Thirdly, in cases where the applicant is a foreign-owned coneern, how far British oil companies receive equitable treatment in that country. Fourthly, we shall look at the programme of work of the applicant and also at the ability and resources to implement it. Fifthly, we shall look at the contribution the applicant has already made or is making towards the development of resources of our continental shelf and the development of our fuel economy generally". This statement, while discouraging ad hoc speculators, at least bestows Government blessing on and moral backing for those British and allied international oil concerns who have in the past sponsored and paid heavily for underwater search for favourable structural indications of oil and gas pools offshore of these Islands.

The regulations provide for exploration licences giving the right to search for oil in an area stretching from the Straits of Dover to the Shetland Islands, and approximately halfway across the North Sea, excludirg areas already subject to exclusive licences. Such licences will cost $£ 1,000$ per annum each. Production licences will cost $£ 10$ per square mile for the first six years, increasing after that annually by increments up to as much as $£ 120$ per square mile. Should oil production be established at any site, operators will pay royalties of 12.5 per cent of the value of oil or gas at well-head, this being roughly in line with procedure in other oil-bearing countries. Costs of annual sums incurred in exploration will be deductæble from royalties which, on the face of it, seems an extremely fair basis of contract, always providing of course that 